\title{
ВПЛИВ ПЕРВИННИХ ФАКТОРІВ ДОБОРУ НА РОБОЧІ ЯКОСТІ СОБАК СУПРОВОДУ
}

\author{
Була Людмила Валер'янівна \\ кандидат сільськогосподарських наук \\ Сумський національний аграрний університет \\ ORCID: 0000-0002-4698-9307 \\ E-mail: bula.snau@gmail.com \\ Свисенко Софія Валеріївна \\ аспірант спеціальності 204-ТВППТ \\ Сумський національний аграрний університет \\ ORCID: $0000-0001-8761-7676$ \\ E-mail: ursula1708@ukr.net \\ Павленко Юлія Миколаївна \\ кандидат сільськогосподарських наук, доцент \\ Сумський національний аграрний університет \\ ORCID: 0000-0002-4128-122X \\ E-mail: jasjulia@ukr.net
}

При проведенні досліджень вивчались матеріали звітів змагань з прикладних видів підготовки собак за національною програмою «Відсіч» Всеукраїнської громадської організації «Кінологічна спілка України» за 2019-2020 рр. Оцінка робочих якостей за програмою «Собака супроводу» проводилась за 50-ти бальною шкалою відповідно демонстрації твариною 5 навичок: охоронна, захисна робота, реакиія на ласощі і звук пострілу, а також підлеглість та керованість собаки. Дослідженнями встановлено, що найкращі результати на змаганнях демонструють собаки породи доберман (33,4士2,20

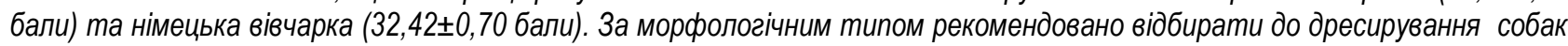

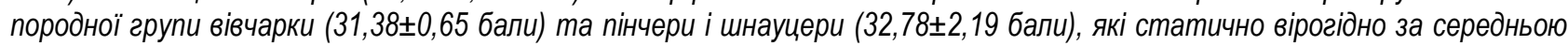
оцінкою робочих якостей $(P \geq 0,99-0,999)$ перевищують показники роботи молосів. Доведено, що статевий диморфізм не впливає на здатність собаки виробляти та застосовувати у реальній ситуації навички захисту за програмою «Собака супроводу». Проте належність тварини до певної породи ( $\left.\eta_{x}^{2}=0,1693 \pm 0,033\right)$, іï морфологічний тип ( $\left.\eta_{x}^{2}=0,073 \pm 0,013\right)$ та вік на час випробувань $\left(\eta_{x}^{2}=0,1133 \pm 0,031\right)$ мають статистично вірогідний $(P \geq 0,99-0,999)$ вплив на показники робочих якостей собак. Під час аналізу впливу вікової мінливості на оиінку роботи собак на змаганнях зроблений припустимий висновок, що для успішної демонстраиії твариною навичок захисту з досліджуваного курсу має значення не тільки вироблення певних інструментальних рефрлексів в процесі дресирування, а й накопичення власного досвіду твариною у рішенні конфрліктних ситуацій з умовним супротивником на базі дозрівання та зміцнення природних інстинктів. Тому рекомендовано збільшити вік тварин для допуску участі у змаганнях та випробуваннях за досліджуваною програмою підготовки захисних собак.

Ключові слова: кінологія, собака супроводу, робочі якості, порода, стать, вік, «Відсіч».

DOI: https://doi.org/10.32845/bsnau.lvst.2020.4.21

У світовому масштабі початком використання собак у службових цілях можна вважати кінець XIX століття. Зокрема у Бельгії в 1899 році діяли два розплідники службових собак, де тварини набували навичок захисної та караульної служби. Приблизно у той же час охоронні собаки з'явились в штаті поліції міста Парижу. На початку XX століття у Німеччині вченими проводилося багато науково-дослідних експериментів і випробувань собак, спрямованих на вивчення їхіх здібностей, поведінки та психології. Беручи до уваги досвід бельгійських та німецьких колег англійці з 1909 року почали створювати розплідники службових собак, поділивши їх на дві групи - розшукові та службово-захисні $[4,6]$.

У 1900 році з появою та цілеспрямованим розведенням німецької вівчарки, у Німеччині була створена система дресирування Schutzhund (дослівно з німецької мови «собаки для захисту, охорони»), за якою регулярно Спілкою власників німецької вівчарки проводились випробування, що включали в себе оцінку навичок слухняності, слідової роботи та захисту у собак.

Із другої половини XX століття Schutzhund стає спортивним напрямком у кінології. У 1989 році Міжнародною Кінологічною Федерацією для іспитів робочих якостей племінних собак службових порід був розроблений еквівалент Schutzhund «Міжнародні правила випробувань та змагань користувальних собак» IGP (Vielseitigkeitsprufung fur Gebrauchshunde nach International Prufungsordnung, до 2019 року називалися «(PO»), за яким щорічно проводиться Чемпіонат Світу. Собаки, які тренувалися за обома системами дресирування, повинні були чітко знайти фігуранта в укритті, обгавкати його та відпрацювати напад в лобову. Недоліком європейських змагань був той факт, що провідник і службовий собака відпрацьовували типізовані завдання, і в реальному житті собака міг не спрацювати $[12,16]$.

На початку XX століття в Україні також приділялася увага службовому собаківництву. Так у 1924 році в Харкові була організована перша школа-розплідник військових і спортивних собак. У ній розроблялися теоретичні основи, методика і техніка розведення службових собак, ї дресиру- 
вання та застосування для розшукової, сторожової і вартової служб. Одночасно велася велика робота з відтворення племінних собак і підготовці фахівців службового собаківництва. У період 60-80-х років XX століття велике значення у прогресі галузі мало Добровільне товариство сприяння армії, авіації і флоту. У цьому товаристві готували кінологів, що знали все про розведення, утримання та дресирування службових собак. Досвід цих спеціалістів дав позитивний результат, адже підготовлені ними собаки щорічно передавались в армію, прикордонним військам та іншим відомствам $[8,14,15]$.

Після проголошення незалежності України розпочався новий етап розвитку кінології, почали створюватися громадські кінологічні об'єднання, з'явились приватні дресирувальні майданчики та майже відразу почалася робота 3 оформлення структури методів національного дресирування собак. Основною рушійною силою цього процесу став київський дресирувальний центр «Зотер». Робота в ньому розподілялась на два напрямки - спортивний («Зотер») та прикладний (секція «Арес), яка в 1997 році відокремилася в самостійну Школу охоронних собак «Арес». Саме «Арес» у 1996 році провів перші загальнонаціональні змагання серед собак супроводу, яких на той час називали охоронцями [10].

Сучасна вітчизняна теорія дресирування ґрунтується на даних багатьох наук, що вивчають поведінку і навчання тварин. Особлива увага при цьому приділяється значенню потреб і емоцій в структурі поведінкового акту. Але у світовому масштабі єдиної методики щодо тренувань собак немає. Кожен із кінологів має своє бачення захисної роботи. Зокрема Олександр Виноград у своїй праці зазначає, що навички захисту, які включають пошук собакою помічника на ділянці місцевості, виявлення та обгавкування ймовірного злочинця, охорону та затримання його призначені для виконання службових завдань. Проте така методика підготовки наближена до спортивного дресирування [1, 4, 5, 7, 11] Досвід застосування собак у реальних ситуаціях та поява нових порід виявили у вітчизняних фахівців сумніви щодо доцільності застосування спортивних методів дресирування захисних собак.

Кінолог Володимир Висоцький, що є засновником Школи охоронних собак «Арес», у 2000 році офіційно відокремив систему дресирування охоронних собак від захисних (супроводу). У 2013 році всі названі програми разом з традиційною «Караульною службою» були об'єднанні в комплекс національних програм «Відсіч» єдиною системою оцінювання. У своїх працях він зазначає, що ці програми були розроблені на основі класичних національних систем дресирування, але значною мірою модернізовані з урахуванням сучасних реалій, прив'язані до конкретних побутових ситуацій і позбавлені «армійського службового підходу».
Вони є зорієнтованими значною мірою на потреби пересічних громадян та приватних охоронних структур [2].

Найбільшу зацікавленість серед населення викликала програма «Собака супроводу». Суть її полягає в тому, що дресирувальники і ймовірні супротивники моделюють певну ситуацію і змушують собаку проявити агресію (фізично проявити свою вроджену агресивність), закріплюючи її в цій конкретній ситуації позитивним впливом. Собака, що володіє достатнім агресивним потенціалом, охоче «розряджається» потім при виникненні подібної модельованої ситуації (робота без команди) або при застосуванні умовного подразника-команди. Цей процес має ще дві позитивні тенденції: по-перше, собака стає більш дисциплінованим і не намагається «саморозряджатися» там, де цього робити не можна. I, по-друге, об'єктом атаки для такого собаки ніколи не стане член своєї «зграї»[3].

Національна програма «Відсіч» стала популярною не тільки серед українських власників собак, а й викликала зацікавленість у закордонних фахівців, зокрема навчання в Україні пройшли представники багатьох країн (Іспанія, Болгарія, Польща, Росія, США, Білорусь, Словаччина та ін.). Крім того, фахівці Школи охоронних собак "Арес" постійно запрошуються для ведення семінарів і практичних занять в Італію та Іспанію. Так у 2013 році в Іспанії зареєстрована школа «ARES-ESPANA», яка практикує підготовку спеціальних собак за українськими методиками.

Дуже важливим напрямком в роботі українських «прикладників» $€$ співпраця з вітчизняними силовими структурами та армією. «Відсіч» також прийнята як програма підготовки та випробувань в Міжнародній поліцейській корпорації громадської безпеки $[2,3,10]$.

Враховуючи актуальність застосування якісно підготовлених собак супроводу як у Збройних силах України та інших силових структурах держави, так і у системі сек'юріті, метою наших досліджень було вивчення первинних факторів добору тварин, а саме впливу породної належності, статевого диморфізму та віку собак на показники їхніх робочих якостей за програмою «Собака супроводу».

Матеріали та методи досліджень. При проведенні досліджень вивчалися матеріали звітів змагань із прикладних видів підготовки собак Всеукраїнської громадської організації «Кінологічна Спілка України» (КСУ) за 2019-2020 роки. Оцінка робочих якостей собак проводилась згідно Положення КСУ «Про порядок проведення випробувань та змагань за програмою «Собака супроводу», яка відноситься до Комплексу охоронних та захисних програм «Відсіч» [13].

Оцінка робочих якостей кожного собаки проводилась за 50-ти бальною шкалою відповідно демонстрації твариною п'яти навичок (табл. 1):

Порядок нарахування балів за програмою змагань «Собака супроводу»

Таблищя 1

\begin{tabular}{|c|c|c|c|}
\hline $\begin{array}{l}\text { № } \\
\text { П/п }\end{array}$ & Навичка & $\begin{array}{c}\text { Максимальна } \\
\text { кількість балів }\end{array}$ & Умови, за які можуть бути нараховані штрафрні бали \\
\hline 1. & $\begin{array}{l}\text { Охоронна } \\
\text { робота }\end{array}$ & 15 & $\begin{array}{l}\text { Укус підставленого предмета з «переключенням». } \\
\text { Відсутність попереджувальної поведінки. } \\
\text { Слабкий укус. } \\
\text { Чутливість до групового тиску. } \\
\text { Формальна робота, контактність. } \\
\text { Пропуск ймовірного противника (ВПР) до прив'язі. } \\
\text { Відмова від роботи. }\end{array}$ \\
\hline 2. & Захисна робота & 20 & Укус в «ухватку» переключенням. \\
\hline
\end{tabular}

Вісник Сумського національного аграрного університету 


\begin{tabular}{|c|c|c|c|}
\hline $\begin{array}{l}\text { № } \\
\text { п/п }\end{array}$ & Навичка & $\begin{array}{c}\text { Максимальна } \\
\text { кількість балів }\end{array}$ & Умови, за які можуть бути нараховані штрафні бали \\
\hline & & & $\begin{array}{l}\text { Слабкий укус/слабкий удар намордником. } \\
\text { Зацікавленість м'ячом. } \\
\text { Формальна робота, постановочна азартність. } \\
\text { Пропущений удар ножом. } \\
\text { ВПР доторкнувся до власника. } \\
\text { Атака «заручника з/без переключення в ВПР. } \\
\text { Відмова від роботи.» }\end{array}$ \\
\hline 3. & $\begin{array}{l}\text { Реакція } \quad \text { на } \\
\text { ласощі }\end{array}$ & 8 & $\begin{array}{l}\text { Принюхується, цікавиться ласощами. } \\
\text { Бере в пащу, але не їсть. } \\
\text { Не бере, але ловить на льоту. } \\
\text { Поїдає, або боїться ласощів. }\end{array}$ \\
\hline 4. & $\begin{array}{l}\text { Реакція на звук } \\
\text { пострілу }\end{array}$ & 2 & $\begin{array}{l}\text { Не реагує на постріл або чутлива до нього. } \\
\text { Боїться пострілу (дискваліфікація). }\end{array}$ \\
\hline 5. & $\begin{array}{l}\text { Підлеглість та } \\
\text { керованість } \\
\text { собаки }\end{array}$ & 5 & $\begin{array}{l}\text { Труднощі при керуванні собакою. } \\
\text { Неуважність до власника. } \\
\text { Поганий контакт з власником. } \\
\text { Реакція заміщення. } \\
\text { Грубе поводження з собакою (дискваліфікація). }\end{array}$ \\
\hline
\end{tabular}

Біометрична обробка одержаних даних проводилась методом варіаційної статистики за формулами, наведеними Е.К. Меркурьевой и Г.Н. Шангин-Березовским [9].

Ступінь впливу факторів на робочі якості собак розраховувався за допомогою однофакторного дисперсійного аналізу. Величина критерію вірогідності встановлювалася при рівнях: $P \geq 0,95 ; P \geq 0,99$ та $P \geq 0,999$ за допомогою критеріїв Стьюдента і Фішера.

Математична обробка статистичного матеріалу проводилась за допомогою ЕОМ з використанням програмного забезпечення фірми "Microsoft" (операційна система
"Windows-10", електронні таблиці “Excel”).

Результати досліджень. У 2019-2020 роках на змаганнях Кінологічної Спілки України з курсу дресирування «Собака супроводу» програми «Відсіч» приймало участь 211 собак, більшість з яких - породи німецька вівчарка $51,17 \%$ (табл. 2). Середні бали загальної оцінки роботи собак згідно породних груп за підсумками змагань були

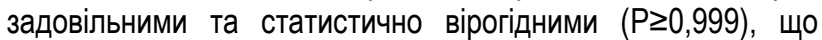
вказує на підтверджену здатність тварин досліджуваних порід формувати навички за вказаною програмою дресирування.

Таблиця 2

Оцінка собак різних порід за програмою «Собака супроводу», балів

\begin{tabular}{|c|c|c|c|c|}
\hline № & Порода & $\mathrm{n}$ & $\mathrm{M} \pm \mathrm{m}$ & $\mathrm{Cv}, \%$ \\
\hline 1. & Американський пітбультер'р & 8 & $30,75 \pm 2,54^{* * *}$ & 12,1 \\
\hline 2. & Американський стафффордширський тер'єр & 17 & $27,53 \pm 1,79^{\star \star \star}$ & 15,37 \\
\hline 3. & Бельгійська вівчарка (малінуа) & 17 & $27,24 \pm 1,84^{* * *}$ & 27,8 \\
\hline 4. & Доберман & 5 & $33,4 \pm 2,20^{* * *}$ & 14,76 \\
\hline 5. & Кане корсо & 32 & $28,88 \pm 1,36^{\star * *}$ & 26,71 \\
\hline 6. & Німецька вівчарка & 108 & $32,42 \pm 0,70^{* * *}$ & 22,57 \\
\hline 7. & Ротвейлер & 7 & $17,57 \pm 2,11^{* * *}$ & 31,83 \\
\hline 8. & Східноєвропейська вівчарка & 10 & $27,20 \pm 2,00^{* * *}$ & 23,24 \\
\hline 9. & Інші породи & 7 & $26,00 \pm 3,84^{* * *}$ & 39,03 \\
\hline \multicolumn{2}{|c|}{ В середньому } & 211 & $30,08 \pm 0,55^{\star \star \star}$ & 26,38 \\
\hline
\end{tabular}

Найкращі результати на змаганнях демонстрували собаки породи доберман - 33,4 2 2,20 бали та німецька вівчарка - 32,42 $\pm 0,70$ бали, найнижчий середній бал $(17,57 \pm 2,11)$ був зафріксований у собак породи ротвейлер. Проте різниця між середнім арифметичним бальної оцінки робочих якостей собак порівняльних порід була вірогідною тільки за декількома досліджуваними групами. Так, оцінка робочих якостей доберманів була вірогідно вищою тільки у порівнянні $з$ показниками роботи бельгійських вівчарок малінуа $\left(D_{M}=6,16\right.$ бали, $\left.P \geq 0,95\right)$ та ротвейлерів $\left(D_{M}=15,83\right.$ бали, $P \geq 0,999)$. Результати роботи за навичками досліджуваного курсу німецьких вівчарок були кращими в порівнянні з більшою кількістю породних груп, а саме: на 4,89 бали вищі (P $\geq 0,98)$, ніж у американських стаффордширських тер'єрів, на 5,18 балів $(P \geq 0,99)$ порівняно до бельгійських вівчарок (малінуа), 5,22 бали ( $\mathrm{P} \geq 0,99)$ порівняно до східноєвропейських вівчарок та на 15,15 балів $(P \geq 0,999)$ порівняно до ротвейлерів. Собаки інших порід мали вірогідно вищий середній бал оцінки роботи на змаганнях тільки у порівнянні до породи ротвейлер.

Необхідно звернути увагу на те, що в породних групах, які мали найнижчий середній бал оцінки навичок курсу, а саме ротвейлери та собаки групи інших порід, коефіцієнт варіації був найвищим (31,8\% та $39.03 \%$ відповідно). Це вказує на те, що в цих групах були тварини, які демонстрували як відмінні робочі якості, так і не задовільні.

Для більш ретельного аналізу впливу породної належності собак на їхні робочі якості з навичок захисту ми згрупували тварин за морфологічним типом генетичного походження породи, виділивши чотири дослідні групи, а саме (табл. 3):

- вівчарки, до яких відносяться німецька, бельгійська та східноєвропейські вівчарки;

- молоси - ка де бо, кане корсо, німецький боксер та 
ротвейлер;

- пінчери та шнауцери - різеншнауцер, російський чорний тер'єр та доберман;
- молосоїдні тер'єри - американський пітбультер'єр, американський стаффордширський тер'єр та бультер'єр.

Вплив морфологічного типу породи на робочі якості собак оцінених за програмою «Собака супроводу», балів

\begin{tabular}{|l|c|c|}
\hline \multicolumn{1}{|c|}{ Тип } & $\mathrm{n}$ & $\mathrm{M} \pm \mathrm{m}$ \\
\hline Вівчарки & 135 & $31,38 \pm 0,65^{\star * *}$ \\
\hline Молоси & 41 & $26,29 \pm 1,35^{* * *}$ \\
\hline Пінчери та шнауцери & 9 & $32,78 \pm 2,19^{* * *}$ \\
\hline Молосоїдні тер'єри & 26 & 33,00 \\
\hline
\end{tabular}

${ }^{*} P \geq 0,95 ;{ }^{* *} P \geq 0,99 ;{ }^{* * *} P \geq 0,999$

Аналізуючи дані таблиці 3 ми бачимо, що найкращий результат з курсу «Собака супроводу» демонструють пінчери та шнауцери, середній бал яких складає 32,78 бали, найнижчий середній бал $(26,29)$ мають собаки групи молосів, причому бальна оцінка робочих якостей молосів була статистично вірогідно меншою як до групи пінчерів і шнауцерів $\left(D_{M}=6,496 а л и, ~ P \geq 0,99\right)$, так і вівчарок $\left(D_{M}=5,09\right.$, $\mathrm{P} \geq 0,999)$. Враховуючи той факт, що у програмі «Собака супроводу» більше звертається уваги на навички захисту людини, а не охорони майна, можливо припустити, що саме морфологічний тип породи зокрема ії генетичне походження, впливають на захисні якості тварини. Також необхідно відмітити, що саме в групі молосів простежується найбільша мінливість оцінки робочих якостей собак ( $\mathrm{Cv}=33,0 \%)$.

Як вітчизняні, так і закордонні дресирувальники при відборі собак до використання у захисно-охоронних службах перевагу віддають псам, як більш потужним та здатним постійно знаходитися у робочий кондиції порівняно до сук, на яких впливає фізіологічний статевий цикл. Так, і в наших дослідженнях більша частка собак, які демонстрували свою роботу на змаганнях, а саме $68,25 \%$, були пси. Проте аналізуючи результати бальної оцінки робочих якостей собак різної статі виявилось, що різниця була незначною і статистично невірогідною (табл. 4). Тому можна зробити висновок, що статевий диморфізм не впливає на дресирування тварин за програмою «Собака супроводу».

Таблиця 4

Вплив статевого диморфізму на оцінку захисних навичок собак, балів

\begin{tabular}{|l|c|c|c|}
\hline \multicolumn{1}{|c|}{ Стать } & $\mathrm{n}$ & $\mathrm{M} \pm \mathrm{m}$ & $\mathrm{Cv}, \%$ \\
\hline Пси & 144 & $30,48 \pm 0,67$ & 26,29 \\
\hline Суки & 67 & $29,21 \pm 0,95$ & 26,54 \\
\hline Все поголів'я & 211 & $30,08 \pm 0,55$ & 26,38 \\
\hline
\end{tabular}

Згідно Положення КСУ «Про порядок проведення випробувань та змагань за програмою «Собака супроводу» до участі у змаганнях допускаються собаки, які досягли віку
12 місяців. Як бачимо з рисунку графічного розподілу тварин, які приймали участь у змаганнях, за віком, основне поголів'я собак (86,3 \%) було до 5 років включно (рис.1).

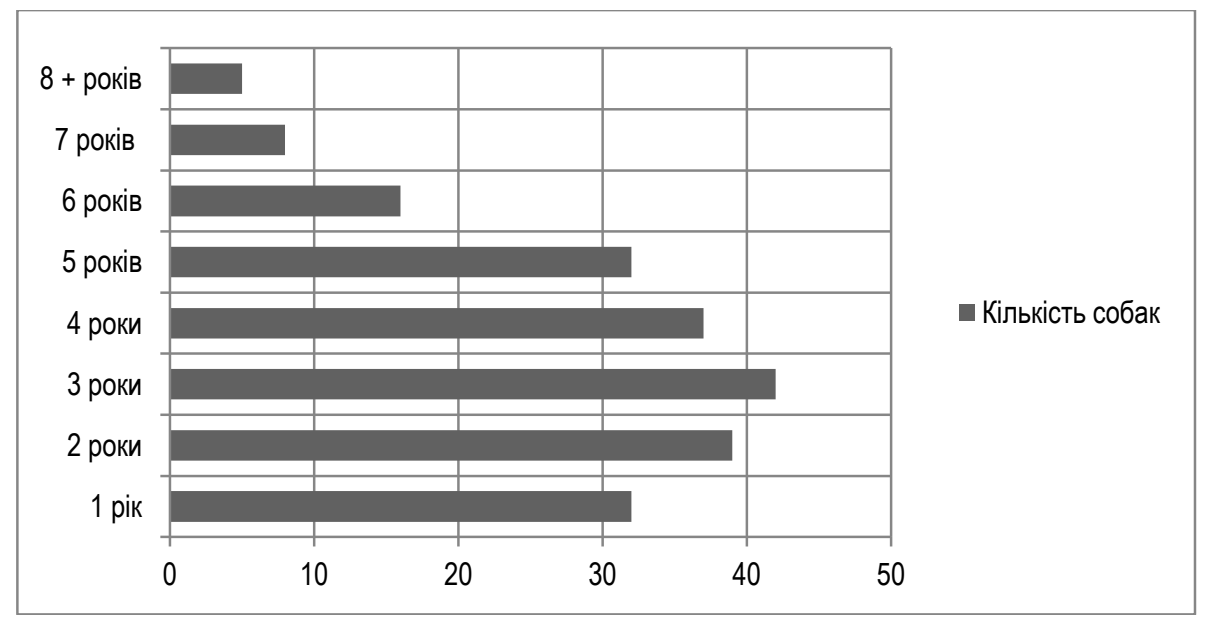

Рис. 1. Поголів'я, що було розподілене на вікові групи

За даними таблиці 5, у якій відображена оцінка роботи собак різного віку, ми бачимо тенденцію до підвищення показників бальної оцінки робочих якостей захисних собак 3 віком до п'яти років включно (33,88 бали). У цьому випадку різниця даних оцінки навичок на змаганнях п'ятирічних собак у порівнянні до одно-, двох- та трирічних тварин була статистично вірогідною ( $\mathrm{P} \geq 0,99-0,999)$. Також статистично вірогі-

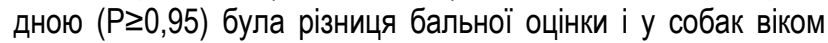
три роки порівняно з наймолодшою групою. Це можна пояс- нити тим фактом, що з віком собаки збільшують свій досвід роботи з навичок захисту. Особливістю програми «Відсіч» порівняно до спортивних курсів дресирування захисних собак $€$ те, що випробування проводяться кожен раз у різних умовах та за різним сценарієм для подальшої універсальності собаки в роботі. Тому, можливо припустити, що для успішної демонстрації твариною навичок захисту з досліджуваного курсу має значення не тільки вироблення певних інструментальних ресрлексів в процесі дресирування, а й 
накопичення власного досвіду твариною у рішенні конфліктних ситуацій з умовним супротивником на базі дозрівання та

зміцнення природних інстинктів.

Таблиця 5

Результати змагань собак різного віку, балів

\begin{tabular}{|c|c|c|c|}
\hline Вік на момент змагань & $\mathrm{n}$ & $M \pm m$ & Cv, $\%$ \\
\hline 1 & 32 & $25,56 \pm 1,57^{* * *}$ & 34,72 \\
\hline 2 & 39 & $28,59 \pm 1,13^{* * *}$ & 24,68 \\
\hline 3 & 42 & $29,21 \pm 1,04^{* \star *}$ & 23,14 \\
\hline 4 & 37 & $31,19 \pm 1,46^{* * *}$ & 28,54 \\
\hline 5 & 32 & $33,88 \pm 1,20^{* * *}$ & 20,06 \\
\hline 6 & 16 & $32,69 \pm 1,56^{\star * *}$ & 19,08 \\
\hline 7 & 8 & $33,75 \pm 2,53^{* * *}$ & 21,23 \\
\hline $8+$ & 5 & $31,00 \pm 3,81^{* * *}$ & 27,47 \\
\hline
\end{tabular}

Проводячи аналіз вікової мінливості робочих якостей собак хочемо звернути увагу на той факт, що однорічні тварини мали не тільки найнижчу бальну оцінку порівняно 3 іншими віковими групами, але й найбільший коефріцієнт варіації $34,72 \%$, що вказує на значну мінливість ознаки в межах досліджуваної групи. Вочевидь подібні змагання $є$ значним випробуванням для молодого собаки, у якого ще певним чином, можна сказати, не достатньо сформовані інстинктивні форми поведінки, які необхідні для протидії супротивнику. Тому рекомендуємо збільшити вік тварин для допуску участі у подібних змаганнях.
Враховуючи всі досліджувані показники, нами розраховано частку впливу розмаїтості первинних фракторів відбору тварин на мінливість оцінки робочих якостей за програмою дресирування «Собака супроводу» (рис.2). На відміну від статевого диморфізму $\eta_{x}^{2}=0,0056 \pm 0,005$ (P<0,95), вплив породної належності тварини $\eta_{x}^{2}=0,1693 \pm 0,033$, морфологічного типу $\eta_{x}^{2}=0,073 \pm 0,013$ та вікового фактору $\eta_{x}^{2}=0,1133 \pm 0,031$ на оцінку робочих якостей $€$ невеликим, але статистично вірогідними ( $\mathrm{P} \geq 0,99-0,999)$.

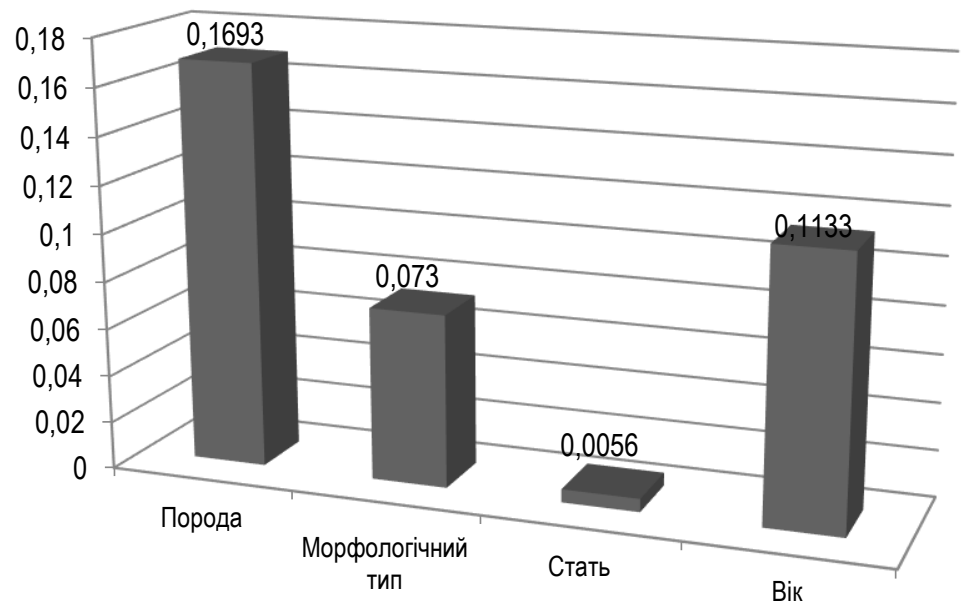

Рис.2. Вплив факторів первинного відбору на мінливість оцінки робочих якостей собак, $\eta_{x}^{2}$

Висновки. У результаті проведення досліджень проаналізований вплив первинних факторів відбору на оцінку робочих якостей собак за програмою дресирування «Собака супроводу», яка відноситься до національного комплексу підготовки захисно-охоронних собак «Відсіч». Встановлено, що найкращі результати на змаганнях демонструють собаки породи доберман та німецька вівчарка. За морфологічним типом породи рекомендовано відбирати до дресирування собак породної групи вівчарки та пінчери і шнауцери, які статично вірогідно за середньою оцінкою робочих якостей перевищують показники роботи молосів. Доведено, що статевий диморфізм не впливає на здатність собаки виробляти та застосовувати у реальній ситуації навички захисту за програмою «Собака супроводу». Під час аналізу вікової мінливості оцінки робочих якостей собак зроблений припустимий висновок, що для успішної демонстрації твариною навичок захисту з досліджуваного курсу має значення не тільки вироблення певних інструментальних рефлексів в процесі дресирування, а й накопичення власного досвіду твариною у рішенні конфліктних ситуацій з умовним супротивником на базі дозрівання та зміцнення природних інстинктів. Тому рекомендовано збільшити вік тварин для допуску участі у змаганнях та випробуваннях за досліджуваною програмою підготовки захисних собак.

\section{Список використаної літератури:}

1. Виноград О. В. Теоретичні основи дресирування службових собак. Давидківці: ФОП Мельник А. А., 2020. 254 с. 
2. Висоцький В. Б. "Відсіч" - український шлях у робочому собаківництві. Club Dogs. 2017. Вип. 1 (16), С. 66-71.

3. Высоцкий В. Б. Собака сопровождения. М.: АСТ, 2001. 30 с.

4. Гайдук С. В. Основи дресирування, гігієни та годівлі службових собак. К.: "Інтерсервіс", 2017. 176 с.

5. Дьюет К. Ф. К-9 - собака для охраны и защиты собственности и бизнеса. М.: Центрполиграф, 1997. 236 с.

6. История развития служебного собаководства [Електронний ресурс]. - Режим доступy:https://fccu.com.ua/wp content/plugins/downloadattachments/includes/download.php?id=133 (дата звернення 24.03.2020).

7. Козоріз Д. Декілька слів про агресію. Club Dogs. 2018.Вип. 3 (21), С. $162-167$.

8. Лебедев В. И. Полицейская сторожевая собака. Санкт-Петербург: Издание Российского общества поощрения применения собак к полицейской и сторожевой службе, 1908. 22 с.

9. Меркурьева Е. К., Шангин-Березовский Г. Н. Генетика с основами биометрии. М.: Колос, 1983. 400с.

10. Методичні вказівки по підготовці собак по комплексу охоронно-захисних програм «Відсіч» [Електронний ресурс] . - Режим доступу: http://varlay.com.ua/index.php?idname=22var83. (дата звернення 22.03.2020)

11. Нагорічна О. С., Бережнюк І. Г., Пунда О. О. Кінологічне забезпечення Державної фіскальної служби України. Хмельницький: ФОП Мельник А. А., 2015. 348 с.

12. Павленко К. Не ламатися, оберати мету й досягати ї̈. Club Dogs. 2018. Вип 3 (21), C. 122-127.

13. Положення Всеукраїнської громадської організації "Кінослогічна спілка України" "Про порядок проведення випробувань та змагань за програмою "Собака супроводу"'" [Електронний ресурс]. - Режим доступу: http://uku.com.ua/oficial_inform/all_polozh.html (дата звернення 01.04.2020).

14. Фатин Д. А. Собаки специального назначения: рассекреченые методики подготовки охранных собак. М.: Центрполиграф, 2008. $334 \mathrm{c}$.

15. Шутенко О. О., Красьоха Я. В. Основи службової кінології: навчальний посібник для підготовки фрахівців-кінологів. К.: ДП "Друкарня МВС України", 2008. 312 с.

16. International Utility Dogs Regulations (IGP) for the international Utility dog trials, international Tracking dog trial, international Companion dog trial, international Article search trials, international Endurance trial of the $\mathrm{FCl}$ [Електронний ресурс]. - Peжим доступу: http://www.fci.be/medias/UTI-REG-IGP-49-2020-en-12995.pdf (дата звернення 22.03.2020).

\section{References:}

1. Vynohrad O. V.,2020. Teoretychni osnovy dresyruvannia sluzhbovykh sobak [Theoretical bases of training of service dogs]. Davydkivtsi: FOP Melnyk A. A.

2. Vysotskyi V. B., 2017. "Vidsich" -ukrainskyi shliakh u robochomu sobakivnytstvi ["Vidsich" - ukrainian way in working dog breeding]. Club Dogs, issue 1 (16), pp. 66-71.

3. Vysotskyi V. B., 2001. Sobaka soprovozhdenyia [Accompanying dog]. M.: AST.

4. Haiduk S. V., 2017. Osnovy dresyruvannia, hihiieny ta hodivli sluzhbovykh sobak [Basics of training, hygiene and feeding of service dogs]. K.:Interservis.

5. Diuet K. F.,1997. K-9 - sobaka dlia okhrany y zashchyty sobstvennosty y byznesa [K-9 - dog for guarding and protecting property and business] M.: Tsentrpolyhraf.

6. The history of the development of service dog breeding. Availabe at: <https://fccu.com.ua/wp content/plugins/downloadattachments/includes/download.php?id=133> [Accessed 24 March 2020).

7. Kozoriz D., 2018. Dekilka sliv pro ahresiiu [A few words about aggression]. Club Dogs, issue 3 (21), pp. 162-167.

8. Lebedev V. Y., 1908. Polytseiskaia storozhevaia sobaka [Police guard dog]. Sankt-Peterburh: Yzdanye Rossyiskoho obshchestva pooshchrenyia prymenenyia sobak k polytseiskoi y storozhevoi sluzhbe.

9. Merkureva H. N. and Shanhyn-Berezovskyi E. K., 1983. Henetyka s osnovamy byometryy [Genetics with the basics of biometrics]. M.: Kolos.

10. Methodical instructions on preparation of dogs on a complex of security and protective programs «Vidsich» available at: $<$ http://varlay.com.ualindex.php?idname=22var83> [Accessed 22 March 2020).

11. Nahorichna O. S., Berezhniuk I. H. and Punda O. O., 2015. Kinolohichne zabezpechennia Derzhavnoi fiskalnoi sluzhby Ukrainy [Cynological support of the State Fiscal Service of Ukraine]. Khmelnytskyi: FOP Melnyk A. A.

12. Pavlenko K., 2018. Ne lamatysia, oberaty metu y dosiahaty yii [Do not break, choose a goal and achieve it.]. Club Dogs, issue 3 (21), pp. 122-127.

13. Regulations of the All-Ukrainian public organization " Ukrainian Kennel Union " "On the procedure for conducting tests and competitions under the program "Accompanying dog"'. Available at: <http://uku.com.ua/oficial_inform/all_polozh.html>.[Accessed 01 April 2020].

14. Fatyn D. A., 2008. Sobaky spetsyalnoho naznachenyia: rassekrechenye metodyky podhotovky okhrannykh sobak [Special Purpose Dogs: Declassified Methods of Training Guard Dogs]. M.: Tsentrpolyhraf.

15. Shutenko O. O. and Krasokha Ya. V., 2008. Osnovy sluzhbovoi kinolohii: navchalnyi posibnyk dlia pidhotovky fakhivtsivkinolohiv [Fundamentals of service cynology: a textbook for training cynologists]. K.: DP "Drukarnia MVS Ukrainy".

16. International Utility Dogs Regulations (IGP) for the international Utility dog trials, international Tracking dog trial, international Companion dog trial, international Article search trials, international Endurance trial of the $\mathrm{FCl}$. Available at: <http://www.fci.be/medias/UTI-REG-IGP-49-2020-en-12995.pdf> [Acessed 22 March 2020]. 
Bula Liudmyla Valerianivna, PhD of Agricultural Sciences, Sumy National Agrarian University

Svysenko Sofiia Valeriivna, graduate student, Sumy National Agrarian University

Pavlenko Yuliya Mykolayivna, PhD of Agricultural Sciences, Docent, Sumy National Agrarian University

Influence of primary selection factors on working quality accompanying dogs

During the research, the materials of the reports of competitions on applied types of dog training under the national program "Vidsich" of the All-Ukrainian public organization "Ukrainian Kennel Union" for 2019-2020 were studied. protective work, reaction to treats and the sound of an arrow, as well as the subordination and controllability of dogs. Studies have shown that the best results in competitions are shown by dobermans (33.4 \pm 2.20 points) and german shepherds (32.42 \pm 0.70 points). According to the morphological type of the breed, it is recommended to select shepherds (31.38 \pm 0.65 points) and pinschers and schnauzers (32.78 \pm 2.19 points) for training dogs, which are statically probable according to the average assessment of working qualities $(P \geq 0,99-0,999)$ exceed the performance of molossus. It has been proven that sexual dimorphism does not affect the dog's ability to develop and apply protection skills in the real situation under the program "Accompanying dog". However, the affiliation of the animal to a certain breed $\left(\eta_{x}^{2}=0.1693 \pm 0.033\right)$, its morphological type $\left(\eta_{x}^{2}=0.073 \pm 0.013\right)$ and the age at the time of the tests $\left(\eta_{x}^{2}=0.1113 \pm\right.$ 0.031) are statistically probable $(P \geq 0.99$ - 0.999) the impact on the performance of dogs. During the analysis of age variability of evaluation of dogs in competitions, it is possible to conclude that for successful demonstration of animal protection skills from the studied course it is important not only to develop certain instrumental reflexes in the training process, but also to accumulate animal experience in conflict situations. the basis of maturation and strengthening of natural instincts. Therefore, it is recommended to increase the age of animals to participate in competitions and trials under the studied program of training protective dogs.

Key words: cynology, accompanying dog, working qualities, breed, sex, age, "Vidsich".

Дата надходження до редакції: 17.11 .2020 p. 